\title{
TRANSFORMATION OF SOCIAL CAPITAL INTO ECONOMIC CAPITAL THROUGH EDUCATION (BY THE EXAMPLE OF THE EUROPEAN UNION AND BULGARIA)

\author{
Petar Lyudmilov Parvanov ${ }^{1}$, Nadezhda Emilova Petkova ${ }^{2}$
}

\begin{abstract}
This paper is an analysis of different types of capital as well as of the opportunity for capital to be transformed into various types. The basic sorts of capital and their theoretical conceptions are being viewed with an attempt to prove that every resource should be considered as capital as long as they bring benefits which can be regarded as economic ones. Education and knowledge are important factors for the process of observing and analyzing the transformation of human or social capital into economic capital. On the basis of statistic data from Eurostat it is shown in this paper that there is a direct dependency between education and the economic growth of a given country. The main objective of the paper is to present the theoretical opportunities for capital transformation and to give examples for the latter through data from Eurostat. Moreover, we accept the working hypothesis that capital should be related to the personality that it belongs; and that in its essence it is uniform and it takes different forms through transformation. For the writing of the text we have used comparative and theoretical methods, adaptive methodology, deductive and empirical method and the statistical analysis method. The main outcomes of our research are as follows: capital exists in various forms; it can be transformed and it should be defined as a resource that brings additional dividends; human capital, albeit personal. Through its social function it is transformed into economic one and is useful not only for the individual but for society as a whole; education is one of the fundamental ways for human and social capital accumulation. There is a direct correlation between education and economic growth. Moreover, on the basis of the examples from the data from the European Union, it is clear that the more educated young people there are in the real economy, the higher the economic development is.
\end{abstract}

JEL Classification Numbers: A14, J24, I25, DOI: 10.12955/cbup.v7.1368

Keywords: social capital, economic transformation, education, economic growth.

\section{Introduction}

Economic processes become more and more dynamic and comprehensive in contemporary society. The boundaries are blending and every human activity leads to economic results and it can be regarded as such. As Swedberg (2003) writes, this results in the fundamental scientific dispute on whether economics is a separate science or whether is it a part of the comprehensive subject of sociology. Also, whether a subject of sociology, under the name "economic", is a part of economics or is it a science which studies only a part of human relations. Zimel (1997) points out that in the end, a person is a creature of society and every activity they do, including economic ones, is placed in a particular habit and correspondingly in a particular discourse. According to Friedman (1953) a person is a rational being in their economic actions. On the other hand, Hayek (1979) allows for the fact that human emotion and awareness also have economic measurability and thus they should strictly follow certain rules or in other words they should be institutionalized in order to be economically active and people themselves must be free in their actions. The aim of the following paper is to show the opportunity for capital to acquire different forms one of which is through education. It is expected the contribution of the following research to show on the basis of theoretical analysis and statistical data the opportunities for creation and transformation of social capital into economic. As an example we have given the creation of social capital through education.

\section{Literature review}

One cannot exactly say which one of the statements on economic activity is accurate and we do not believe that we should go to extremes. Thus, it should be presumed that a person is lead in their economic activities by not only rational and sensible actions, but also by their emotions with the end result of economic reality being determined by the aggregation of a given personality's actions in the environment that we live in. The main concepts on social capital and its transformation are presented in Rakadhiyska's article "Social capital as personal achievement in a network social structure" and Stoilova's article named "The person and their social capital".

Here, we should also rest on the postulates of the Austrian School of Economic Thought and their views presented by Vurbanov (2000) and Koeva (2003) being that economy is socially structured and one does not live in order to accumulate material goods but to improve their social status with the

\footnotetext{
${ }^{1}$ South-West University "Neofit Rilski", Faculty of Economics, Department of Economics, Blagoevgrad, Bulgaria, petarparvanov@gmail.com

2 South-West University "Neofit Rilski", Faculty of Economics, Department of Economics, Blagoevgrad, Bulgaria, nadya.petkova@swu.bg
} 
material goods being subjected to this aim (and we would say vice versa as well). Consequently, the relation between economy, law, politics, traditions and morals are considered as systematically relevant, ensuring a person's and society's development. As Hayek (1996) writes, we live in a society in which we successfully orient ourselves and in which our actions can achieve their goals not only due to the fact that the ones similar to us are led by familiar goals or by known relations between goals and resources but also because they follow rules whose aim and origin we are often unaware of and the existence of which we often do not even assume of. Also as Blau (1998) concludes, the main prerequisite for the theory on social exchange are that people enter new social alliances because they hope to be rewarded or they do not break relations with their old associates and they expand their cooperation with them because they actually realize that this brings them rewards. We can conclude that, as Bourdieu (2005) comments, every action which leads to a person having power over another person may be considered as an economic one.

Following these statements, it can be concluded that at the basis of an economic action are all human actions; and whether they are economic ones or not depends on their intention. In the end, as Hayek (1996) writes, goods are gained in accordance with the order in a society. Due to this reason we should consider that the development of capital in it and the economic utility that it leads to should be reviewed as a transformation process. We should accept that a given type of capital can easily be transformed into another one as long as the person who possesses it has interest from this and has an opportunity to realize it. At the basis of capital acquisition, as Koeva (2001) discusses Hayek's views, is knowledge which is subjective and evolutionary and it coordinates society and helps economic processes.

Ricceur (2004) found that the system of acquirement of knowledge, skills and competencies and their usage should be transferred not only on purely economic activities of a person but also on their every activity which leads to economic results depending on the intention and that depending on its intention the activity should be considered as economic one. Also, according to Bourdieu (1997) actions are cognitive structures which drive cognitive forms of perception that are applicable in all social structures.

This is the reason why the society creates an order which is projected through institutions and guarantees consistency and growth of profits, no matter whether it is material or social. Bourdieu (1997) indicates that the projection can inseparably ensure the reproduction of a structure in the relations of domination and dependency. Also, as Sedlarski (2009) points out, the economic processes are influenced by economic activity as well as morals, religion, education and culture.

The variety in research methods and approaches in economics leads to a diversity in the interpreting and understanding of fundamental economic terms as well as in the opportunity for them to be transformed. This is the reason why we accept the working hypothesis that capital should be related to the personality that it belongs; and that in its essence it is uniform and it takes different forms through transformation. The latter itself should be considered as a social process in which the individual establishes themselves. The capital, irrespectively of its form, brings usefulness not only for the individual himself/herself but also for the society which they belong to.

The expanded vision of capital leads to the differentiation between different types of capital in terms of it being a resource that brings income, some of which are: economic capital which originates directly from economic activity; social capital - as far as from economic activities a general good for all beneficiaries concerned - networks, relations, etc. is being created; human capital which belongs to the person but that is also infused into the social capital of the community, a part of which is the person. In this sense the very individual is an owner of human, social, economic and other types of capital.

One of the main researchers of social capital, Putnam (2013), claims that in analogy to the term material capital and social capital - means and qualifications increasing individual productivity, the term "social capital" characterizes those aspects of the social organization such as networks, norms and social trust which facilitate coordination and mutually beneficial cooperation. Therefore, social capital is defined as a public good - a good for everyone. It represents everything that is public.

Apart from Robert Putnam, other main researchers of social capital are: Pier Bourdieu, John Coleman and Mark Granovetter (1999) with his view that economic behavior is a social structure based on social relations. 
According to Bourdieu (1984) social capital is a combination of real or potential resources related to the ownership of a long-lasting network of more or less institutionalized relations of mutual cognition and acknowledgements. Also, as discussed in a work from Rakadzhiiska, Misheva and Hristova (2015), the agents are united by particular relations but these relations cannot be related to the objective relations of closeness in the physical area or even in the economic and social area as they are built on exchanges that are inseparably material and symbolic and their establishment and existence supposes a recognition of this closeness.

Coleman (1999) asserts that, first of all, social capital is every aspect of the informal social organization which constitutes a productivity resource for one or more actors. He also states that it is possible for people to invest in social capital rationally. Furthermore, the social organization usually depends on informal relations which have been established for non-economic purposes, despite having economic consequences. Lastly, according to him one of the activities having an economic aspect and whose importance for the social capital has been already established is education.

It is clear that social capital is related to people and society. They are its subjects and its formation and usage are interrelated processes. They happen at the same time. According to Pachev (2007) social capital is every aspect of an informal social organization. This type of capital is inseparably connected to its bearers who are the people and society as a whole. Consequently, social capital is unalterably related to human capital with both types of capital mutually permeating each other and creating an action of their own which can be measured with economic results. As Kazakov (2010) points out, human capital is formed and is the result of the impact on original human material, through which new quality of labor that can be applied as a factor service is achieved. He also adds that human capital expresses the accumulated knowledge, experience, acquired skills and the resulting qualification, combined with the health status of the bearer of these new properties, their motivation, talent and ability to handle information.

As it has become clear, human capital is the combination of knowledge and skills of a person that they develop throughout their life, irrespectively of the matter in which they acquire them - formally or informally. We assume that primarily education, along with the other factors that form human capital such as family environment, upbringing, etc., stands at the basis of human capital acquisition. Each individual contributes to the formation of social capital through the implementation of their human capital and this process consequently has economic consequences. Among the main theorists of the Human capital theory, which in recent years is considered to be one of the main factors of economic activity, are Jacob Mincer, Gary Becker, Theodore Schultz and Robert Gibbons.

According to Nedelchev (2004) the types of social, respectively human capital, are subdivided according to its functions and depending on the context and the culture in which it is located. He found that social capital is accumulated through social relations. It is the foundation of social structures. Moreover, as Coleman (1999) states, social capital depends on the characteristics of the social structure and in particular on the closeness of social networks, the continuity in social relations and their complexity. He also says that one of the activities that have an economic aspect and for which the importance of social capital is demonstrated is education - the opportunity of a person to acquire knowledge, skills and competences that depends on the conditions created by the society and the skills of the individual.

In this respect we must keep in mind the fact that the development of human capital is cumulative, depending on the acquired throughout a person's development personal qualities and on all that they have gained (knowledge, skills and competences) over their personal and professional life which can be considered as human capital. Human capital development also depends on the environment in which one develops, since every individual is limited by their habit and their actions are realized in a certain discourse in order for social capital to be generated. Factors that can be qualified as internal and external have influence on the development discourse itself. The internal ones are the relations in the very discourse and the external ones are the common rules that influence the relations within the discourse. These factors are further subdivided into formal and informal which in the spirit of the institutional economy must be seen as legal and moral norms of behavior. All these conditions allow the person to develop or not their human capital and to transform it into social and correspondingly into economic one. Kamenov (2011) mentions that this transformation may be positive or negative, as well as complete or partial, with it depending on the skills and capabilities of the capital owner. 


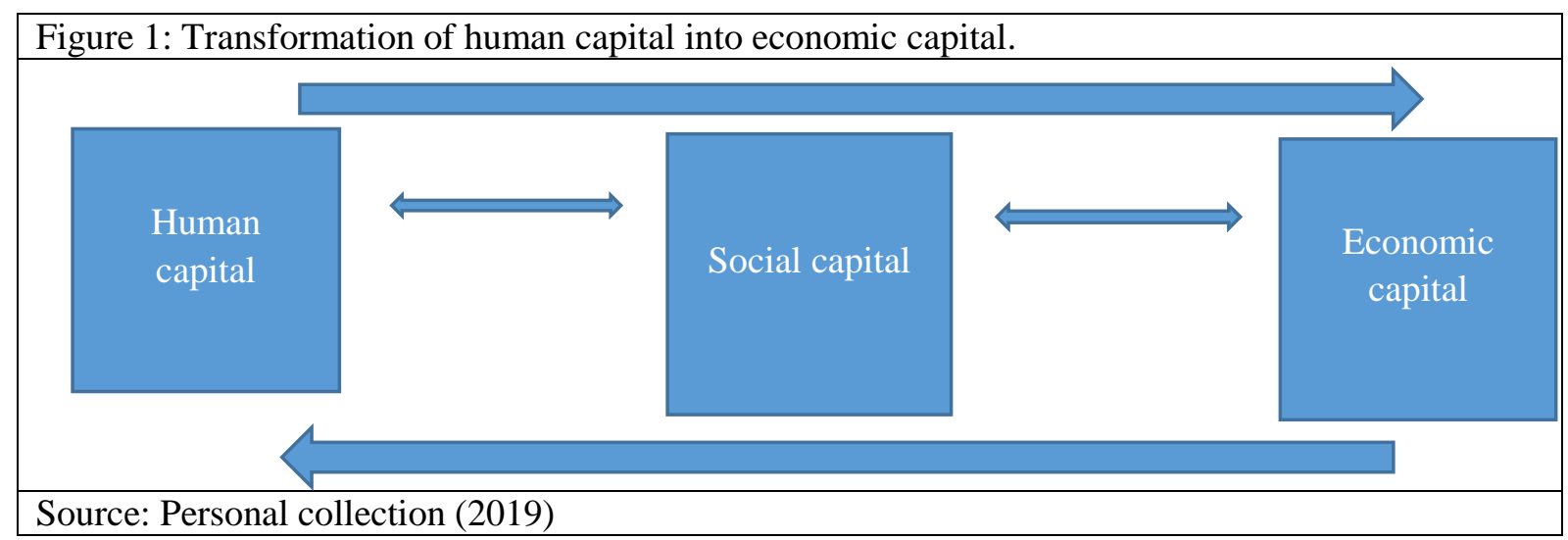

\section{Data and methodology}

Considering the assumption that education, together with other factors that shape human capital such as family environment, upbringing, etc., are fundamental for the human capital acquisition and development it is important to view the level of effectiveness of the education system as such. In our opinion the most important indicator for the effectiveness of an educational system, regardless of the level of education - secondary or higher - is the employment level of graduates from the corresponding level of education. Reason being the fact that employment is inextricably linked with the economic growth in a given country. Using the opportunities that the flexible fragmentation adaptive method allows, we consider the graduates' data are indicative enough in proving the hypothesis laying in the basis of our research.

As we mentioned, the aim of the following paper is to show the opportunity for capital to acquire different forms one of which is through education. Moreover, a substantial part of the acquisition of human, respectively social capital is due to education. Thus, it is appropriate to see how, according to statistical data, it influences the economic development of the countries of the European Union and in particular the Republic of Bulgaria.

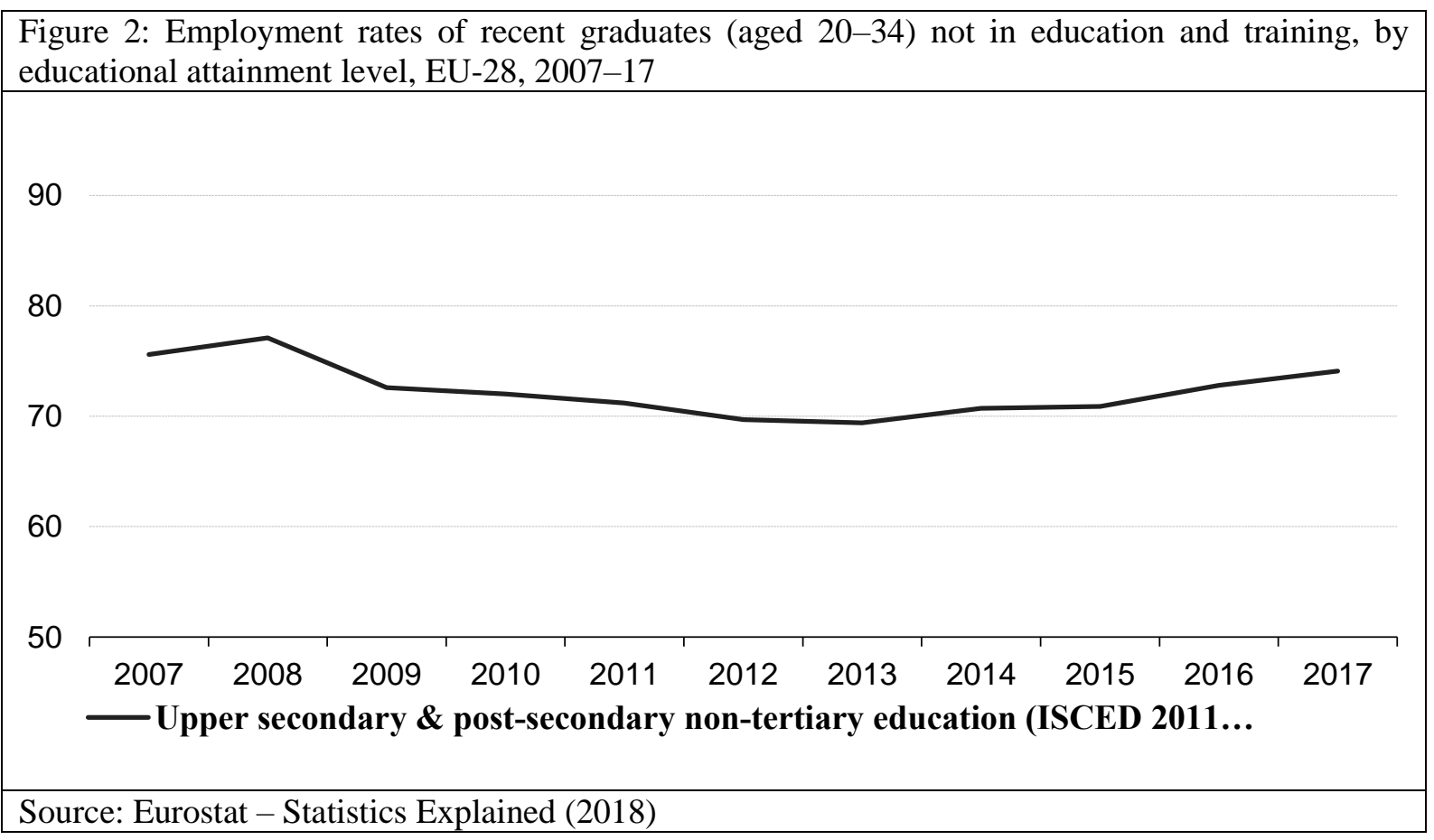

The graph above shows the change in the level of employment rates for secondary school graduates aged 20-34 in the European Union for the period 2007-2017. The highest reported value for this period is $77.1 \%$, followed by a gradual drop in employment to $69.4 \%$ in 2013 , mainly due to the global crisis and its consequences, after which the indicator starts to rise.

The following graph shows in percentages the level of employment of graduates in EU secondary education in 2017. The lowest rate of employment is in Greece - 35.9\% and the highest one is in the 
Czech Republic $-88.6 \%$. The average value for the European Union is $64.1 \%$, with Bulgaria ranking $17^{\text {th }}$ place with $62.5 \%$.

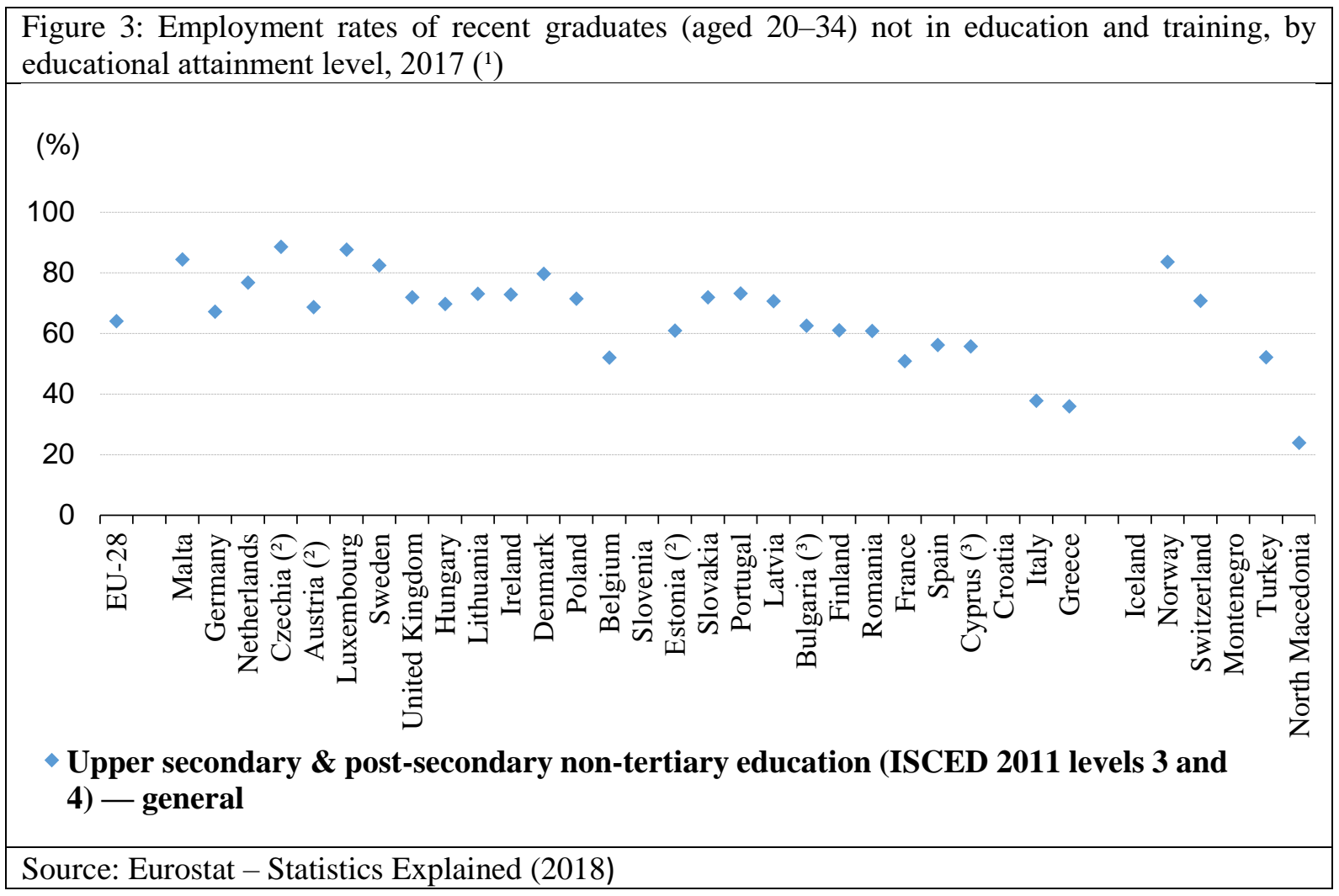

Figure 4: Employment rates of recent graduates (aged 20-34) not in education and training, 2007 and $2017\left({ }^{1}\right)$

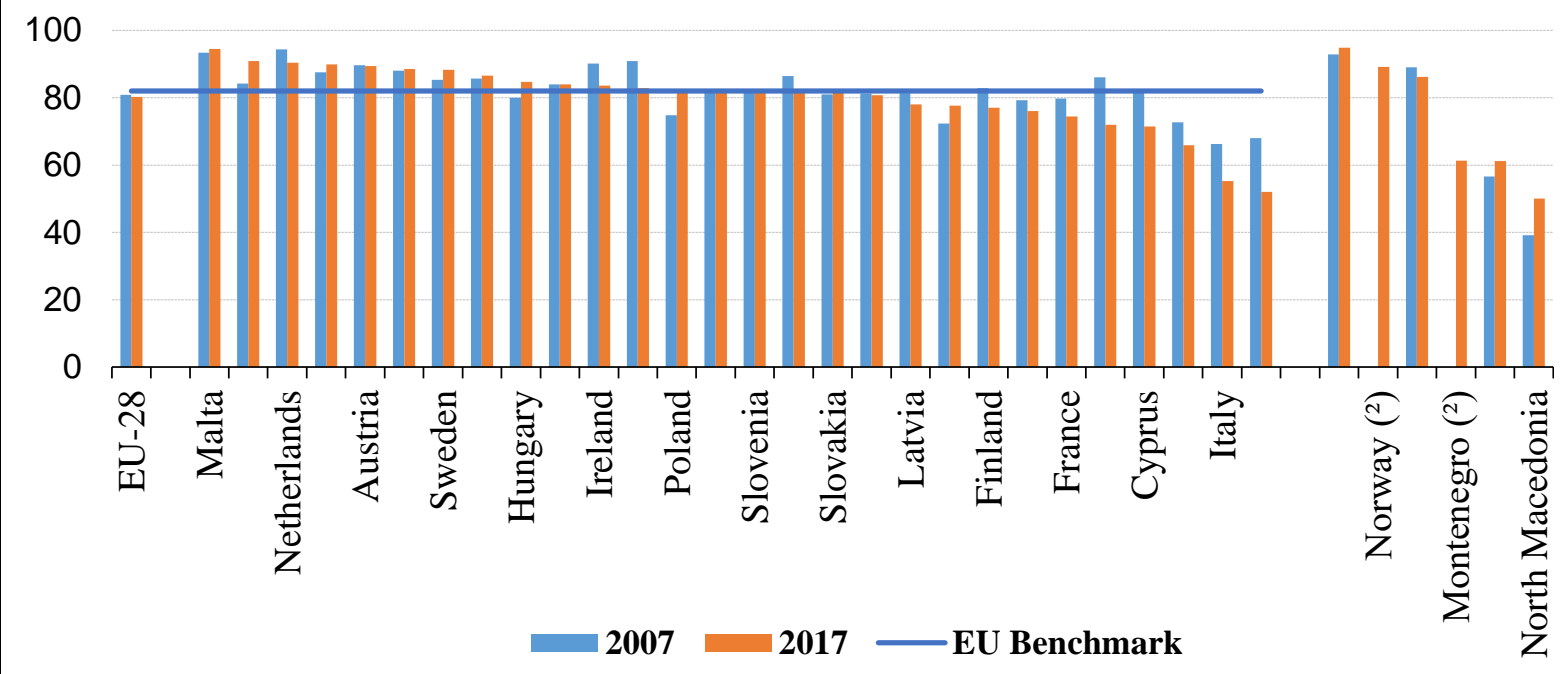

Source:Eurostat - Statistics Explained (2018)

Figure 3 shows a comparison of the employment rate of secondary school or tertiary education graduates among all EU member states for the years 2007 and 2017. The benchmark for this indicator in the EU is $82 \%$. The highest numbers for both years are observed in Malta - 93.4\% in 2007, and respectively $94.5 \%$ in 2017. The lowest rates recorded are again in Greece $-68 \%$ and 52\% for 2017 . The employment rate of graduates for Bulgaria for 2007 is $72.3 \%$ and it is close to, yet lower than the value of the EU benchmark of $82 \%-77.7 \%$. 
As additional prove for our hypothesis the data from the following research can also be presented: "New doctorate graduates (ISCED 6) per 1000 population aged 25-34"1; "New graduates in science, maths, computing, engineering, manufacturing, construction per 1000 population" ", "Population age 25-34 having completed tertiary education"3; “"

\section{Research Results}

We believe that the data provided by Eurostat are widespread and representative for the aim of our research which we believe will set the beginning for future research that would prove the diverse human activity based on capital and education as being only one part of it. We have used comparative and theoretical methods, adaptive methodology, deductive and empirical method and the statistical analysis method. The main outcomes of our research are as follows: capital exists in various forms; it can be transformed and it should be defined as a resource that brings additional dividends; human capital, albeit personal, through its social function is transformed into economic one and is useful not only for the individual but for society in which it is realized as a whole; education is one of the fundamental ways for human and social capital accumulation. There is a direct correlation between education and economic growth. Moreover, on the basis of the examples from the data from the European Union, it is clear that the more educated young people there are in the real economy, the higher economic development $\mathrm{i}$

An important factor for the successful professional establishment of the graduates not only in Bulgaria but in the EU as a whole is the correspondence between the labor market needs and the area of qualifications that young people acquire through their education. Parvanov, Krastev and Atanasova (2018) found that the labor market is starting to experience increasing difficulties in finding highly specialized workers due to the demographic crisis and the aging population. Moreover, steady economic growth is accepted as a natural foundation for achieving social security and development and for society's social cohesion (Kicheva et al., 2018).

\section{Discussion and Conclusion}

On the basis of the information and data above the contribution of our research leads to the following conclusions: the processes of capital transformation through education are as follows: capital exists in various forms; it can be transformed and it should be defined as a resource that brings additional dividends. Also, human capital, albeit personal, through its social function is transformed into economic one and is useful not only for the individual but for society in which it is realized as a whole. Furthermore, education is one of the fundamental ways for human and social capital accumulation.

We believe that the research can be continued with the development of theoretical works on the transformation of one type of capital into another having in mind the contemporary dynamic way of life and the always transforming human activities, one part of which being education. The research can be continued in other fields connected to social economy as well, such as healthcare, culture, upbringing, etc. The difficulties we faced in the following research paper are related to the lack of specific research about the forms and ways of capital transformation as there are many research related to the different types of capital and not to its transformation.

All in all, there is a direct correlation between education and economic growth. Moreover, on the basis of the examples from the data from the European Union, it is clear that the more educated young people there are in the real economy, the higher economic development is.

\section{References}

Becker, G. S. (1962). Investment in Human Capital - a theoretical analysis. The Journal of Political Economy, 70(5), 9-49. https://doi.org/10.1086/258724

Blau, P. (1998). Sotsialna razmyana [Social exchange]. Izvori na sociologiyata, 580-581.

Bourdieu, P. (1984). Distinction: A Social Critique of the Judgement of Taste. Harvard: Harvard University Press. https://doi.org/10.1080/10848770.2013.772046

\footnotetext{
${ }^{1}$ https://rio.jrc.ec.europa.eu/en/stats/new-doctoral-graduates-thousand-population-aged-25-34 Retrieved: 03, September, 2019;

${ }^{2}$ http://appsso.eurostat.ec.europa.eu/nui/show.do?dataset=educ_uoe_grad04\&lang=en_Retrieved: 03, September, 2019;

${ }^{3}$ https://data.oecd.org/eduatt/population-with-tertiary-education.htm_Retrieved: 03, September, 2019;
} 
Burdiio, P. (1997). Prakticheskiyat razum [The Practical Mind]. Sofia: Kritika i khumanizum

Burdiio, P. (2005). Prakticheskiyat uset [The Practical Sense]. Sofia: Figura.

Coleman, J. (1986). Social Theory, Social Research and a Theory of Action. The American Journal of Sociology, 91 (6), 1309-1335. https://doi.org/10.1086/228423

Coleman, J. (1988 ). Social Capital in the Creation of Human Capital. The American Journal of Sociology, 94, 95-120.

Employment rates of recent graduates. (2019, March). Retrieved from ec.europa.eu: https://ec.europa.eu/eurostat/statisticsexplained/index.php/Employment_rates_of_recent_graduates

Friedman, M. (1953). Essays in Positive Economics. Chicago: University of Chicago Press.

Gibbons, R. (1992). Game Theory for Applied Economists. Princeton: Princeton University Press.

Granoveter, M. (1991). Ikonomichesko deistive i sotsialna struktura.[Economic Action and Social Structure] Antologiya, Ikonomika i Sotsiologiya,191.

Hayek, F. (1979). Law, Legislation and Liberty. Chicago: University of Chicago Press.

Kamenov, K. (2011). Modelirashta sreda i choveshki potentsial [A Modelling Environment and Human Potential]. Dialog, 3 , $14-24$.

Kazakov, A. (2010). Choveshkiyat kapital:kontseptualna ramka i funktsionalna metodologiya [Human Capital: conseptual framework and methodology], Nauchni trudove na UNSS, 1, 22.

Khaiek, F. (1996). Pravo, zakonodatelstvo i svoboda [Law, Legislation and Liberty] (Vol. 1). Sofia: UI "SV.K.Okhridski".

Kicheva, M., Petkova, N., \& Bogdanova, M. (2018). The Impact of Globalization on the Development of Human Potential in an Innovative Socio-cultural sphere and Opportunities for Social Entrepreneurship. Proceedings of 18th International Scientific Conference on Globalization and Its Socio-Economic Consequences., 2160-2161.

Koeva, S. (2001). Epistemologichnata ikonomika na F.A.Khaiek [Epistemological Economics of K.A. Hayek], Godishnik, 19.

Koeva, S. (2003). Avstriiskata ikonomicheska shkola. Otlichitelni cherti i individualni postizheniya [Austrian Economic School. Characteristics and individual achievements], Varna: STENO.

Koulmun, D. (1999). Perspektivata na ratsionalniya izbor za ikonomicheskata sotsiologiya [The Perspective of Rational Choice for Economic Sociology], Antologiya, Ikonomika i Sotsiologiya, 78-79;91.

Mincer, J. (1993). Studies in Human Capital. Cheltnam: Edward Elgar Publishing.

Nedelchev, D. (2004). Sotsialen Kapital i ikonomichesko razvitie [Social Capital and Economic Development], Sofiya: AI "Marin Drinov".

Pachev, T. (2007). Sotsialen kapital i vliyanieto mu vurkhu ikonomicheskoto razvitie [Social Capital and its Influence on economic development]. Ikonomicheski alternativi(1), 4-5.

Parvanov, P., Krastev, V., \& Atanasova, I. (2018). Legal Opportunities for the Development of Social Enterprises Human Potential in Bulgaria. Proceedings of 18th International Scientific Conference on Globalization and Its Socio-Economic Consequences., 1280 .

Putnam, R. (2013). Da igraesh bouling sam i namalyavashtiyat sotsialen kapital na Amerika [Playing Bowling Alone and the Decreasing Social Capital of America], Kritika i khumanizum(41), 175.

Rakadzhiiska, T., Misheva, T., \& Khristova, M. (2015). Sotsialniyat kapital kato lichnostno dostoyanie v mrezhovata sotsialna struktura (Bulgarskiyat sluchai) [Social Capital as a Personal Achievement in the Network of the Social Structure]. Nauchni trudove na UNSS, 199.

Rikyor, P. (2004). Samiyat sebe si kato nyakoi drug [Myself as noone else].Pleven: EA.

Schultz, T. W. (1961). Investment in Human Capital. The American Economic Review, 51(1), 1-17.

Sedlarski, T. (2009). Neformalni institutsii, ideologii i tranzaktsionni razhodi [Informal institutions, ideologies and transactional exprenses]. Sotsiologicheski problemi(34), 139-154.

Stoilova, V. (2010). Razmyana i opazaryavane [Exchange and Market]. Nauchni trudove na UNSS, 1, 60.

Stoilova, V. (2012). Chovekut i negoviyat socialen capital [The Person and Their Human Potential]. Nauchni trudove na UNSS, 1,195- 217.

Swedberg, R. (2003). Principles of Economic Sociology. Princeton University Press.

Vladimirova, K. (2007). Choveshkiyat potentsial za ikonomicheski rastezh i konkurentosposobnost na bulgarskata ikonomika. Ikonomicheski i sotsialni izmereniya [Human Potential for Economic Estimates and Competititveness of THE Bulgarian Economic. Economic and Social Dimensions. Godishnik na UNSS, 4, 124-174.

Vladimirova, K. (2012). Upravlenie na choveshki resursi i politiki za resurs ili za potentsial na razvitie i sotsialen progres. Godishnik na UNSS, 4, 95-138.

Vurbanov, I. (2000). Ikonomicheskata filosofiya na Fridrikh Haiek. Ikonomicheski izsledvaniya, 3, 63-91.

Zakhariev, A. (2011). Prospektivni razmisli za choveshkiya kapital. Dialog, 3, 104-110.

Zimel, G. (2002). Sotsiologiya. Veliko Turnovo: PIK. 